\title{
THE QUALITY OF LIFE IN MELBOURN, CAMBRIDGESHIRE, IN THE PERIOD 1800-50
}

For most of the present century economic and social historians have intermittently debated the question of the standard of living during the first phase of the Industrial Revolution, 1780-1830. ${ }^{1}$ As both the "pessimists" and the "optimists" acknowledge, too much emphasis can easily be placed on wage levels and the more easily measured aspects of the question, to the neglect of the quality of life and its non-quantifiable aspects. Insufficient explicit attention has also been paid to the divergent experience of different occupations and different districts of the country.

The value of a widely based analysis of local evidence has recently been demonstrated by Levine's study of Shepsed, a large industrial village in Leicestershire. Using demographic as well as social and economic data, he puts beyond question the fact that this village, and probably many other similar villages in the area, suffered great hardship between about 1825 and 1850. This period he described as one of "industrial involution", in which the hosiery industry has passed its peak of prosperity as a domestic occupation, but had not yet been modernised, with steam power and

1 The following books and articles represent a selection of the more recent part of the debate: R. M. Hartwell, "The standard of living", in: Economic History Review, New Series, XVI (1963-64), pp. 135-46; R. M. Hartwell et al., The long debate on poverty: Eight essays on industrialisation and 'the condition of England' (London, 1972); E. J. Hobsbawm, "The standard of living during the Industrial Revolution: A discussion", in: Economic History Review, NS, XVI, pp. 119-34; J. P. Huzel, "Malthus, the Poor Law, and population in early nineteenth-century England", ibid., XXII (1969), pp. 430-52; B. Inglis, Poverty and the Industrial Revolution (London, 1971); several chapters of Land, labour and population in the Industrial Revolution, ed. by E. L. Jones and G. E. Mingay (London, 1967); D. N. McCloskey, "New perspectives on the Old Poor Law", in: Explorations in Economic History, X (1972-73), pp. 419-36; J. P. Marshall, The Old Poor Law 1795-1834 (London, 1968); M. E. Rose, "The allowance system under the New Poor Law", in: Economic History Review, NS, XIX (1966), pp. 607-20; id., The relief of poverty 1834-1914 (London, 1972); E. P. Thompson, The making of the English working class (Harmondsworth, 1968), chs 7 and 10. 
factories, to make it competitive once more against foreign competition. ${ }^{2}$ In the present article I wish to deploy broadly similar data for the village of Melbourn, situated ten miles south of Cambridge in one of the great corn-growing districts of Eastern England. ${ }^{3}$ Before plunging into the details of local history, however, it will be profitable to look at the wider context of the economic and social geography of rural England at this time.

This section explores the broad distinctions that can be drawn between arable and pastoral districts, between industrial and non-industrial areas, and, at the local level, between "open" and "close" or "closed" villages."

Although some form of mixed farming was still practised in most areas of England, specialisation by end-product was already a marked feature of agriculture by the beginning of the nineteenth century. Now this bears upon our central theme from at least three main angles, first in relation to the demand for labour, secondly as regards the social structure of farming and, thirdly, in the relationship between farming and rural industries. Corn farming was most important in the lighter-soil areas situated south-east of a

2 D. Levine, "The demographic implications of rural industrialization: A family reconstitution study of Shepshed, Leicestershire, 1600-1851", in: Social History, No 2 (1976), pp. 177-96; see also id., Family formation in an age of nascent capitalism (New York, 1977). Other local studies are G. J. Barnsby, "The standard of living in the Black Country during the nineteenth century", in: Economic History Review, NS, XXIV (1971), pp. 220-39, and R. S. Neale, "The standard of living, 1780-1844: A regional and class study", ibid., XIX, pp. 590-606 (the latter related to labourers at Bath).

${ }^{3}$ I wish to acknowledge research grants from the Open University and the Social Science Research Council in respect of this work, which is described in my article "A social and demographic study of Melbourn, Cambridgeshire, c. 1840", in: Archives, XII (1976). pp. 115-20. Readers may also find it useful to refer to my articles "The christening custom in Melbourn, Cambs", in: Local Population Studies, No 11 (1973), pp. 11-22, and "The peasant culture", in: New Society, XL (1977), pp. 10-12; and to my chapter on Melbourn in Land, kinship and lifecycle, ed. by R. Smith (London, forthcoming). I should also like to thank my research assistants, Mr M. W. Allsworth and Mrs M. Eden-Green, for help with the Melbourn project.

${ }^{4}$ For the background to agricultural change see Land, labour and population, op. cit.; $\mathbf{J}$. D. Chambers and G. E. Mingay, The agricultural revolution 1750-1880 (London, 1966); G. E. Mingay, Enclosure and the small farmer in the age of the industrial revolution (London, 1968). The following books will provide an introduction to the economic and social geography of nineteenth-century Britain: Man made the land: Essays in English historical geography, ed. by A. R. H. Baker and J. B. Harley (Newton Abbot, 1973); P. J. Perry, A geography of 19th-century Britain (London, 1975). On villages, see M. K. Ashby, Joseph Ashby of Tysoe, 1859-1919: A study of English village life (London, 1961); M. A. Havinden, Estate villages (London, 1966); P. Horn, Labouring life in the Victorian countryside (London, 1976); English rural communities: The impact of a specialised economy, ed. by D. R. Mills (London, 1973); Village life and labour, ed. by R. Samuel (London, 1975). 
line drawn from the mouth of the Tees to the mouth of the Exe. The manpower structure of corn farming was geared to the annual harvest crisis, and considerable under- and unemployment at other times of the year had become an accepted feature of this type of husbandry. Although much information on wage levels is available, both for the harvest and other seasons, what we do not know, and cannot ever know accurately, is the amount of time lost during bad weather and slack seasons. ${ }^{5}$ It was, however, considerable as the levels of poor relief help to demonstrate, and one of the reasons why this kind of expenditure increased between 1760 and 1830 must have been the intensification of corn production in the best-suited areas to meet the demands of a rapidly growing population. ${ }^{6}$

Corn growing was both labour- and capital-intensive, requiring much activity with teams of horses ploughing and cultivating to prepare the seed bed. Sowing sometimes remained a hand operation in this period and was followed by weeding. The harvest made demands on the horse teams again, working with wagons, carts and hermaphrodites (two-wheeled carts converted to four-wheeled wagons for the season). This enabled the corn to be stacked in the farm yard, where, in the barns, threshing took up much of the winter. Horses were expensive to keep, especially in areas where grass was in short supply, and during the course of the year they required a wide range of expensive equipment. ${ }^{7}$ Consequently, corn farming favoured the man who could command broad acres and plenty of capital, a fact that widened the gap between farmer and labourer in arable areas almost to an unbridgeable chasm. In Cambridgeshire, it has been shown that the custom of providing for all surviving children in a period of rising population, coinciding with the intensification of corn farming in the sixteenth and early seventeenth centuries, was one of the main factors in the break-up of the near-equality of the medieval common-field village. Already by 1524-25 over a half of the adult males in Cambridgeshire were at least partly dependent on wage earning for their livelihood, a proportion far

5 E. J. T. Collins, "Harvest technology and labour supply in Britain 1790-1870", in: Economic History Review, NS, XXII, pp. 453-73; Village life and labour, op. cit., ch. 1; Alfred Power writing in First Annual Report of the Poor Law Commissioners for England and Wales [Parliamentary Papers, 1835, XXXV], p. 223. Mingay, "The transformation of agriculture", in: The long debate on poverty, op. cit., gives an overall survey of the agricultural labourer's position.

6 The Poor Law Report of 1834, ed. by S. G. and E. O. A. Checkland (reprinted 1973), has a useful summary in the introduction. See also B. A. Holderness, "'Open' and 'close' parishes in England in the eighteenth and nineteenth centuries", in: Agricultural History Review, XX (1972), pp. 126-39.

$7 \mathrm{~W}$. Gooch, General view of the agriculture of the county of Cambridge (London, 1813), p. 279. 
ahead of most parts of England. "This very high proportion was probably accounted for by the relatively high population density of the county, and partly by the amount of seasonal labour a corn-growing region demanded." 8 The disappearance of the small farmer, so often attributed to the period of Parliamentary enclosure (1760-1840), was a long drawn-out process in most parts of the country and began as early as the first part of the sixteenth century in some villages.

Manufacturing activities in corn-growing areas were less well developed than those in grassland districts, partly because corn farming occupied a larger amount of capital and labour. Moreover, what manufacturing there was tended to be capital-intensive and therefore in the hands of specialists, often urban specialists, rather than farmers. The difficulty of transporting corn, as compared with the droving of cattle, made it desirable to reduce the bulk close to the area of production, and this was achieved by millers, maltsters and brewers. ${ }^{9}$

Although there is plenty of evidence relating to large-scale sheep and cattle farming in the Tudor period, in the eighteenth century specialised dairy, meat and wool production was mostly an activity of family farms. The tending of cattle and sheep, the milking of cows and the making of butter and cheese were much lighter occupations, and were performed by women and children until well into the present century, whereas most of the work in arable farming was too arduous for any but men and grown lads. This was one of the factors that made grassland farming easy to combine with more or less regular by-occupations, often those associated with domestic industries, of which woollen production was the earliest to reach large proportions. The principle of comparative advantage has been invoked to show why, in seventeenth-century rural England, a wide divergence emerged between large farms in corn-growing areas and small farms in the pastoral zone, combined with labour-intensive manufacturing. ${ }^{10}$

When population growth began again in the middle of the eighteenth century, after a century of slow growth and stagnation, percentage increases were on a scale unknown before, producing labour surpluses also of an unprecedented scale in certain districts. These were mainly the arable, corn-growing areas where there was little industry, although more efficient farming methods adopted at this time, some of them made possible by the enclosure of common fields and wastes, enabled agriculture to make use of some of the extra labour. The problems of under- and unemployment were

\. Spufford, Contrasting communities (London, 1974), pp. 33, 36, 66, 100-01, 136.

9 E. L. Jones, "Agricultural origins of industry", in: Past \& Present, No 40 (1968), pp. 58-71, especially pp. 63-64.

${ }^{10}$ Ibid., pp. 61-63, 69-71. See also the chapter by Joan Thirsk in Man made the land, op. cit. 
compounded by the failure of wage rates to keep pace with rising food costs in the Napoleonic-war period and by the fact that the proletariat were progressively cut off from direct means of subsistence. ${ }^{11}$

Up to 1834 responsibility for this maintenance of the poor fell entirely on the shoulders of each individual village administration. Even after the New Poor Law of 1834 was brought into operation, financial responsibility for the poor remained with the village, although administration was the responsibility of the new unions of parishes. Exceptions were made for certain classes of poor in 1845 and 1848 , but those apart, poor rates were levied on a township or parochial basis until $1865 . .^{12}$ As poor rates, like other local taxation of the period, were levied on occupiers of real estate, they fell more heavily on farmers than on shopkeepers, craftsmen and industrialists, whose businesses were much less land-intensive. Farmers and their chief allies, the large-estate owners, therefore, had a considerable incentive to keep the population in their villages to a minimum. The more they could exclude craftsmen and shopkeepers, with their apprentices and journeymen, as well as the casual farm labourers, the less they might pay in the way of poor rates. Where most of the property was concentrated in the hands of a few large owners, the building of cottages and the opening of village businesses were easily controlled, and so a "closed" village was achieved.

Small proprietors, by contrast, found it difficult to agree on a policy of exclusion. Among them would be significant numbers who were interested in the extra trade that even an increase in the labouring population could bring about, including the building of tenement cottages. Small farmers, even in arable areas, frequently had secondary occupations, such as publican, shopkeeper or craftsman, in which they could make a gain to offset increased expenditure on high poor rates. Pastoral areas made little use of casual labour, and the relatively few hired labourers were obliged to live near the animals for which they had responsibility. The size of farms, the nature of farming work and the development of large country estates all conspired to make closed villages a typical feature of corn-growing areas. ${ }^{13}$

11 The importance of direct subsistence has been underestimated by some of the optimists, e.g., Mingay, "The transformation of agriculture", loc. cit., p. 37, who believed that "Probably the majority of labourers who wanted them possessed cottage gardens or rented allotments in the 19th century." As we shall see, this was not true of Melbourn, and it seems to be a surprising assertion to make for all England.

12 English rural communities, op. cit., pp. 182-88. A full account of the change from parochial to union rating is given by Maurice Caplan, "The New Poor Law and the struggle for union chargeability", in: International Review of Social History, XXIII (1978), pp. 267-300.

13 Holderness, “'Open' and 'close' parishes", loc. cit. 
However, where there were closed villages there had also to be open villages, places where rural services could concentrate and where day labourers could live and travel round to farms in neighbouring closed parishes. ${ }^{14}$ Poor rates in open villages were swollen not only by the number of casual labourers living there, but also by the fact that they were the first to be laid off in bad weather and slack times. Industrial competition for labour in many parts of the pastoral zone helped to keep down levels of poor-law expenditure. Where, however, as in Leicestershire, industry had expanded rapidly, periods of bad trade were capable of creating much more havoc than the vicissitudes of corn farming, simply because population had far outrun the symbiotic relationship with the land on which the principle of rural poor rates was based. ${ }^{\mathbf{1 5}}$

\section{III}

It will now be appreciated that it is impossible to answer questions about the standard of living and the quality of life during the Industrial Revolution without spending some effort on evidence gathered in local communities. This article will not settle the question, if it ever could be settled, but it will provide insights for the general reader, as well as a challenge to other researchers to apply their local material to the same question on a comparative basis.

Melbourn belonged to the specialist corn-growing area of chalkland Cambridgeshire, where the usual rotation of crops in the common fields was wheat, barley and fallow, with the occasional replacement of the fallow on better land by rotation grasses or root crops. There is no direct evidence of the latter type of development in Melbourn itself, although some of the soil on the lower slopes near the village was regarded as being of a high grade. Common-field agriculture, therefore, appears to have continued undisturbed until the enclosure of 1839. At this time about 300 acres lay in old enclosures, mostly the built-up area and small grass closes nearby, and about 800 acres constituted the commonable "wastes" of moor and heath. The remaining 3,500 acres were in common field, indicating the predominance of corn farming, and the survey of 1836 leaves no doubt that

14 English rural communities, p. 189; Caplan, loc. cit., pp. 270-72.

15 D. R. Mills, "Landownership and rural population with special reference to Leicestershire in the mid-19th century" (Leicester Ph.D. thesis, 1963), ch. 6 and Appendix 6; id., "English villages in the eighteenth and nineteenth centuries: A sociological approach, Pt I: The concept of a sociological classification", in: The Amateur Historian, VI (1965), pp. 271-78. Poor rates of two or three shillings in the pound were quite common in 1847 in industrialised villages in Leicestershire, while figures below one shilling were more typical of wholly agricultural areas. 
half-acre and one-acre strips were still the typical unit of cultivation. In 1867 , when official crop returns began, 57 per cent of the reported land was in corn crops and 11.4 per cent down to rotation grasses.

Melbourn's barley went mainly to the breweries of nearby Hertfordshire, specifically to the towns of Baldock, Royston and Ware, which helped to supply the capital with beer. Similarly wheat produced in South Cambridgeshire found its way by road to London - 41 miles from Melbourn. The larger farmers were able to sustain flocks of sheep, typically numbering about six score, by virtue of having grazing rights on the common fields. Between harvest and ploughing they could be kept on the fields which had already yielded a crop of barley or wheat. At other times of the year it must be assumed that they were kept on the fallow field. These sheep were also sent to the London market. Indeed the relative proximity of London may have been an influence which rescued Melbourn from the worst effects of depression in arable farming between 1815 and 1835.

Although a number of farms in Melbourn ran to several hundred acres and the Hitch brothers owned nearly 1,500 acres between them, the real character of the village was determined by the fact that no less than 163 owners shared the property listed in the enclosure and tithe awards of 1839 . At the bottom of the social scale a handful of agricultural labourers owned their cottages and occasionally a significant acre or two, but the typical owners were small farmers, tradesmen, craftsmen and publicans resident in the village, with an appreciable number of non-resident owners, some of them brewers, shopkeepers, lawyers and the like living in the Hertfordshire towns and Cambridge. Two Cambridge colleges and the Dean and Chapter of Ely were also important owners. So, Melbourn was a good example of an open or peasant village, containing a well-developed rural "middle class", many of them nonconformist, sometimes to the point of passive resistance, as witness their reluctance to baptise children by the normal rites of the Established Church and to pay the church rate intended for the upkeep of the fabric of the parish church. However, there was no industry in Melbourn in the sense of manufacturing for consumption outside the locality. ${ }^{16}$

16 These three paragraphs are based on a wide study of Melbourn documents, plus the following printed references: F. J. Fisher, "London as an 'Engine of economic growth", in: The early modern town: A reader, ed. by P. Clark (London, 1976), p. 213; Victoria County History of Cambridgeshire, ed. by R. F. Salzman, II (London, 1948); Gooch, General view, op. cit., p. 15; C. Vancouver, General view of the County of Cambridge (London, 1794), pp. 77-79; P. Mathias, The brewing industry in England 1700-1830 (London, 1959), pp. 396-98, 403, 439; S. Jonas, "On the farming of Cambridgeshire”, in: Journal of the Royal Agricultural Society of England, VII (1847), pp. 35, 40, 47. 
Table 1. Population of Melbourn, with other areas for comparison

\begin{tabular}{lrrrrrrrr} 
& & & & \multicolumn{4}{c}{$\%$} \\
& 1801 & 1811 & 1821 & 1831 & 1841 & $1801-41$ & 1851 \\
& 819 & 972 & 1,179 & 1,474 & 1,724 & 110.0 & 1,931 \\
Melbourn & 78,659 & - & - & - & 139,808 & 78.0 & 158,790 \\
Rural Cambs.* & 444 & 452 & 643 & 643 & 730 & 63.7 & 776 \\
Meldreth & 202 & 253 & 320 & 345 & 353 & 74.8 & 321 \\
Shepreth & 420 & 448 & 541 & 547 & 610 & 45.4 & 597 \\
Fowlmere & 309 & 298 & 353 & 371 & 466 & 50.1 & 532 \\
Great Chishill & 1,031 & 1,309 & 1,474 & 1,757 & 2,002 & 94.4 & 2,061 \\
Royston & 8.9 & 10.2 & 12.0 & 13.9 & 15.9 & 79.0 & 17.9 \\
England and Wales** & & & & & & & \\
& $*$ & & & & & & & \\
i.e. the geographical county, including the Isle of Ely, but excluding Cambridge Borough. \\
** Rounded figures in millions.
\end{tabular}

Source: Census of England and Wales.

Table 1 indicates that the population more than doubled between 1801 and 1841 . The rate of increase was 30 per cent or so faster than that for the whole of the country and also for rural Cambridgeshire. The gap between neighbouring villages and Melbourn was even greater, and only Royston, a small market town three miles to the south, kept anywhere near Melbourn's growth rate. What had happened during the eighteenth century is problematical, but the best estimate of population change is that the population was about 532 at the time of the hearth tax (1664), and possibly about 650 when more rapid population growth began around $1760-80 .{ }^{17}$ In other words rapid increases were mainly an experience of the period 1780-1851, for at the latter date the peak was reached. The trebling of population raises two sets of interrelated questions: economic questions concerning employment, poor rates and means of direct subsistence (Section IV), and social and demographic questions relating to vital statistics, housing and other measures of the quality of life (Section V).

17 Based on an aggregative analysis of the parish registers and Documents relating to Cambridgeshire villages, ed. by W. M. Palmer and H. W. Saunders (Cambridge, 1926-27), VI. Palmer and Saunders used the multiplier of five persons per hearth, but I have preferred the multiplier of 4.75 used by John Patten, "Population distribution in Norfolk and Suffolk during the sixteenth and seventeenth centuries", in: Transactions of the Institute of British Geographers, No 65 (1975), p. 59. 
Tables 2 and 3 suggest that agricultural employment remained more or less static during the first forty years of the century, hardly surprising in view of the lateness of enclosure, an event which was said to double the produce of a South Cambridgeshire parish. ${ }^{18}$ However, the conclusion that the rapid growth in labour supply was absorbed by the various non-agricultural occupations is difficult to accept, because these were mainly dependent on agricultural demand, which is known to have been generally slack between the end of the Napoleonic Wars and the early years of Victoria's reign. A partial explanation appears to lie in the fact that many tradesmen and craftsmen, and especially the publicans, combined subsistence agriculture with their non-agricultural occupations. The censuses of 1801-31 do not

Table 2. Melbourn, summary of occupations 1801-31

\begin{tabular}{|c|c|c|c|c|}
\hline & $\begin{array}{c}\text { Persons } \\
1801\end{array}$ & $\begin{array}{c}\text { Families } \\
1811\end{array}$ & $\underset{1821}{\text { Families }}$ & $\begin{array}{c}\text { Families } \\
1831\end{array}$ \\
\hline Chiefly engaged in agriculture & 174 & $149(72 \%)$ & $155(65 \%)$ & $156(54 \%)$ \\
\hline $\begin{array}{l}\text { Chiefly engaged in trades, manu- } \\
\text { factures and handicrafts } \\
\text { All others }\end{array}$ & $\begin{array}{r}53 \\
592\end{array}$ & $\begin{array}{l}47 \\
12\end{array}$ & $\begin{array}{r}83 \\
-\end{array}$ & $\begin{array}{l}96 \\
38\end{array}$ \\
\hline & 819 & 208 & 238 & 290 \\
\hline
\end{tabular}

Note the change in methods of recording between 1801 and 1811 . There were 182 households in 1801 . In 1830 the overseer reported 149 labourers above 20 and 43 under 20.

Source: Census of England and Wales; House of Lords Committee on Labouring Poor, p. 398.

Table 3. Melbourn, summary of occupations 1841

Farmers

Farmers' sons, bailiffs, etc.

Agricultural labourers

Other landworkers

Retailers, wholesalers, transport and publicans

Non-industrial craftsmen

Servants

All others

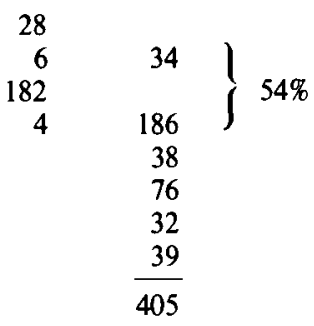

This table includes all heads of households and any males aged 20 or more who were not also heads of households.

Source: 1841 Census enumeration, using Peter Tillott's classification scheme of occupations.

18 House of Lords Committee on Labouring Poor [PP, r830-3I, CCLXXXVII], pp. 391, 394, evidence of Francis Pym Jr, Esq. 
allow for dual occupations and the 1841 enumeration seldom mentions them, but cross reference with the parish registers, land-tax assessments and tithe survey reveals many examples of agricultural interests among those formally recorded as following non-agricultural pursuits. Indeed dual occupations are well-known as a characteristic of open villages, where the existence of small freeholds encouraged their growth.

Another factor to be taken into account is that as Melbourn's population grew it passed thresholds at which it was possible for specialised activities to spring up, serving smaller villages nearby. Examples found in the 1841 enumeration include a surgeon and his assistant, a chemist and his apprentice, two glaziers and plumbers, a fishman (fishmonger?), a bird stuffer, a millwright, an excise officer and a watchmaker. Developments of this kind, however, were limited by the presence of Royston, a market town only three miles away, where professional services such as banking, insurance and legal advice were available. ${ }^{19}$

Melbourn's position astride one of the two turnpike routes between London and Cambridge may also have made some small contribution to the economy of the village, especially as the other route appears to have lost prominence. ${ }^{20}$ In a period when movement depended on the horse, trades such as wheelwrighting, blacksmithing, harness making, carrying and innkeeping, which were all well represented, would stand to benefit from passing traffic, which is likely to have increased between the capital and an important university town.

The most difficult piece of evidence to evaluate in respect of non-agricultural occupations relates to the boarding school run by Rev. William Carver, the Congregational minister (appointed pastor, 1792) and his son William Crole Carver. Among the scholars there in the second decade of the century was the young Samuel Morley, later a member of the Nottingham and London textile firm of I. and R. Morley, and a prominent Liberal and nonconformist politician. This chance has led to the survival of an oft-quoted statistic that the school contained 90 scholars around 1818-20. If this is true, it would have provided a significant amount of employment in the way of servants' work and boarding out, the latter because the premises do not seem to have been anything like big enough to

19 Pigot and Company's Directory of Bedfordshire, Cambridgeshire etc. (London, 1839), pp. 66-67.

${ }_{20}$ E. Carter, History of the county of Cambridge (London, 1819), pp. 188, 262; C. H. Cooper, Annals of Cambridge, IV (Cambridge, 1852), p. 186. The volume of traffic can be gauged by the remembrance of as many as 20 malt wagons at a time drawing up outside the Fox and Hounds at Barley on the old route, J. C. Wilkerson, Two ears of Barley: Chronicle of an English village (Royston, 1969), p. 84. 
accommodate 90 boys, even in the sleeping conditions of the early nineteenth century. The headmaster died in 1825 and in 1831 his son's household contained only 47 people, of whom 12 were servants, two were teachers and nine were in Mr Carver's own family, leaving a maximum of 24 boys. In 1841, 11 boys between the ages of six and fifteen were residing in the school on census night, and by 1851 William Crole Carver was concentrating entirely on his farming activities. Even if the school was important around 1810-20, it declined as Melbourn grew. ${ }^{21}$

Returning to agricultural employment, it is necessary to consider the possibility that labourers found work outside the parish, at least at certain seasons. Substantial regular work in nearby parishes was probably out of the question, through their being similar to Melbourn - open communities with land divided between relatively small owners. The estates of the Earl of Hardwicke at Wimpole (eight miles) and smaller estates at Newsells Park (six miles), Clopton (nine miles) and Shingay-cum-Wendy (seven miles) were the nearest obvious opportunities, but other large settlements, including Barkway, Bassingbourn, Orwell and Royston were better placed to supply them with labour. ${ }^{22}$

Itinerant labourers, however, were not confined to their immediate locality during the busiest seasons of the year. Oxfordshire labourers are known to have gone into the Home Counties to work at the hay harvest, where fodder was got on a large scale for London horses. One of the four Melbourn enumerators in 1841 recorded the absence of six men away at this kind of work on June 6th, which implies a total of perhaps 20 men working from home. Comparison with the parish registers and the 1851 enumeration reveals other absentees, notably a group of related horse dealers and harness makers, who might have been with the haymakers, or at a horse fair, or on a haulage contract. It is also known that labourers from clay parishes in West Cambridgeshire helped with the corn harvest in the chalk areas, where the corn was ready at an earlier date. One might suppose that there was a return flow at a later part of the season from parishes such as Melbourn. ${ }^{23}$

Substantial improvements in agricultural employment can, however,

21 E. Hodder, Samuel Morley (London, 1888), p. 9; E. Porter, "Cambridgeshire schools", in: Cambridgeshire and Peterborough Life (St Ives, Cambs.), December 1968, p. 44; W. M. Palmer Collection, Cambridge University Library, A 3, p. 145; 1831 and 1841 Census enumerations; Cambridgeshire Record Office, 296/SP 39; Tithe survey map, Cambridge University Library; and my reconstitution of Melbourn Parish Registers.

22 Land tax assessments, Cambridgeshire Record Office; Post Office Directory of Nine Counties (London, 1846).

23 Village life and labour, pp. 11-12; 1841 and 1851 Cẽnsus enumerations; my reconstitution of the Parish Registers; Jonas, "On the farming of Cambridgeshire", loc. cit., p. 49. 
only have come with the enclosure of the common fields and "wastes" in 1839. The enclosure itself would create a heavy temporary demand in terms of fencing, ditching and roadmaking. This is graphically illustrated by the traditional story of ploughman Lee, who set out the first boundary a mile and a half long with only one mark on the top of Goffer's Knoll to guide him. ${ }^{24}$

The elimination of fallow and the adoption of more scientific methods of farming, some of it prosecuted from new farmsteads out in the fields, would make a more modest, but more permanent demand on labour, especially as it coincided with an upturn in corn prices. The 1851 Census occurred at a time when the Hitchin-Cambridge railway line was under construction, bringing with it specialist workers from far afield, but also boosting the demand for labourers from nearby villages, including Melbourn. On a long-term basis, the railway was important as a means of exit for surplus agricultural labour, probably towards London, to which the tradition of moonlight removals by donkey cart still survived in the early twentieth century. ${ }^{25}$ In 1846 , the vestry meeting assisted three men to emigrate to Canada, and in 1848 two families were sent to South Australia and one family to Cape of Good Hope. ${ }^{26}$ In facilitating the movement of fruit to the London market, the railway was instrumental in the large-scale establishment of fruit farming, a crop requiring more labour than corn farming, although much of the work was seasonal and capable of being done, as now, by women and children. ${ }^{27}$ Also in the fifties coprolite digging began in the parishes immediately to the north and west of Melbourn. This was a very labour-intensive occupation and it provided Cambridgeshire for a few decades with a source of mineral fertilisers important in a specialist corn-growing economy. ${ }^{28}$ Despite all these developments, Melbourn reached its population peak in 1851 , in itself a suggestion that life must have been hard in the twenties and thirties, when employment prospects and the means of migrating were so much less favourable.

In 1815 , a poor population of 59 , presumably wage-earners out of work, was reported; in 1829 there were said generally to be 40 men and boys employed at digging stones at half wages. At this date Melbourn had one of

${ }^{24}$ Per Mr A. J. Palmer, Cawdon House, Melbourn, whom I wish to thank for much other help.

25 Per Mr M. H. Stockbridge, 2 Orchard Road, Melbourn.

${ }^{26}$ Melbourn Town Book II, pp. 160, 182. I should like to thank the Parish Clerk and the Parish Council for making Town Books II and III available to me.

${ }^{27} \mathrm{~J}$. F. Ward, West Cambridgeshire fruit growing area: A survey of soils and fruit 1925-27 [Ministry of Agriculture and Fisheries Bulletin, No 61] (London, 1933), pp. 30-32.

${ }^{28}$ R. Grove, "Coprolite mining in Cambridgeshire", in: Agricultural History Review, XXIV (1976), pp. 36-43. 
the worst unemployment problems in the area. In 1834180 labourers were said to be sufficient, but the village had a labouring population estimated at 260 over the age of ten. At any time there might be from two or three up to 45 out of work. This statement implies that boys below a certain age were not eligible for relief, and possibly that some farmers were employing men they could have done without. Elsewhere the report states that a labour rate was being tried. This meant that (unemployed?) labourers were being apportioned among occupiers in proportion to the rateable values of their properties. Some of them were digging ground which could equally well have been ploughed, but they were only receiving a piece rate based on the estimated cost of ploughing. In the period March 1834 to December 1835, possibly as an emergency measure in view of the anticipated change in Poor Law administration, the vestry meeting gave orders for the digging of 1,598 cart loads of stone and gravel on the Heath, at the rate of three shillings a load. Despite giving Charles Wright, probably a boy of ten, four shillings a week to take care of the stones during the 1834 harvest, 489 loads were said to have been lost - "not greater than might reasonably be expected under the circumstances of the case" (probably a reference to the Heath being out of sight of the village and crossed by two turnpike roads). The difficulties of employing men fruitfully in this way are further illustrated by the record of payments for stone still owing in October 1836 and the fact of employing men to fill in the holes! ${ }^{29}$

There is plenty of evidence, then, of under- and unemployment, and this together with the wartime rise in corn prices had a calamitous effect on the levels of poor relief (Table 4). As Neale has emphasised, ${ }^{30}$ care must be taken in choosing a base line from which to make comparisons over a period of time and there is little difficulty in demonstrating an improvement of living conditions between 1800 and, say, the early years of the New Poor Law introduced after the 1834 Act. Estimates of per capita expenditure are not easy to make for eighteenth-century Melbourn in view of the absence of good demographic data, nor would these estimates necessarily

29 Melbourn Čènsus enumeration 1841; Town Book II, pp. 1-3, 10-11, 21, 42, 46; House of Lords Committee on Labouring Poor, op. cit., pp. 398-99; A digest of parochial returns to the Select Committee appointed to enquire into the education of the poor [PP, 1819, IX], Pt I [Shannon reprint Poorer Classes, 3], p. 71; Report on the administration of the Poor Laws, Appendix B 1: Answers to rural queries, Pts I-III [PP, 1834, XXX-XXXII], pp. $60 \mathrm{a}, 60 \mathrm{~b}, 60 \mathrm{c}$, being the evidence of William Crole Carver, overseer for Melbourn. Pt I of the Answers to rural queries contains answers to qq. 1-13, Pt II to qq. 14-27, and Pt III to qq. 28-37. Each parish appears on the same page in each volume, e.g., $60 \mathrm{a}, 60 \mathrm{~b}, 60 \mathrm{c}$ for Melbourn, 49 for Bassingbourn, etc. There are five parts altogether, also available as Shannon reprint Poor Law, 10-14.

30 Neale, "The standard of living", loc. cit., pp. 590-92, 602-03. 
Table 4. Melbourn, poor relief 1711-1830

Decade Per capita estimated expenditure (total population), new pence per annum

$1711-20^{*}$

3

$1721-30^{*}$

7

$1731-40$

$1741-50^{*}$

8

1751-60

7

$1761-70$

$1771-80$

$1781-90$

$1791-1800^{*}$

$1801-10$

1811-20

1821-30*

1832-35

* For these decades data ara available for the following numbers of years respectively: $3,8,8,9,8$; the series is complete for other years.

Source: for all years to 1830, Melbourn Town Book I; for 1832-35, First Annual Report of the Poor Law Commissioners, p. 402; the figures in the right-hand column are the estimates given in Answers to rural queries, p. $60 \mathrm{a}$.

prove anything if they were known to be perfectly accurate. Nevertheless, the contrast between 1720 and the early nineteenth century is too striking to be ignored.

The low levels of the early eighteenth century probably reflect two aspects of the relationship between population and the agricultural economy of the village. First, the agricultural demand for labour was probably little different in the 1720's as compared with the 1820's. The steep rise in corn prices in the period 1795-1815 undoubtedly made it profitable to set on more hands to do jobs that might be neglected in less balmy economic conditions, but without enclosing the common field agriculture could not go forward beyond certain limits. Secondly and perhaps more importantly, access to subsistence was almost certainly declining as population increased, a point to which we shall have occasion to return.

Some attempt must be made to compare Melbourn's experience with that of other areas. In 1815, at the peak of national poor-relief expenditure, there were nine other counties in which the proportion of the population relieved was higher than that in Cambridgeshire. In 1834 the rate in the pound at Melbourn was five shillings or upwards, levied on the full rent as valued in 1826 . This was similar to many neighbouring villages, in which figures of about six to nine shillings on two-thirds of the rent were usual. In 1847 , the rate in the pound was $1 / 9 \mathrm{~d}$, compared with the county average of 
$1 / 91 / 4 \mathrm{~d}$ and an average for England and Wales of $1 / 7 \mathrm{~d} .{ }^{31}$ Despite the alarming trend shown in Table 4, Melbourn was, therefore, typical of much of England at this time.

The manner of giving relief also needs to be analysed. The Town Books contain the usual references to widows, the lame, funerals, bastard children, hospitalisation and so forth, but the nub of the issue is whether or not most of the relief took the form of an income subsidy, or whether it was for the payment of men actually out of work. If the bulk of the extra expenditure represented an income subsidy, it could be said to have been occasioned by the farmers' reluctance to pay a living wage in a period of high food prices and to indicate a determination on the part of the community to prevent the erosion of real wages. Unfortunately, the evidence available from Melbourn is not very clear on this point, but what there is does not suggest that incomes were safeguarded very effectively. Against this, it should be noted that corn prices were much lower generally in the 1820 's and 1830's than they had been in the earlier, war, period, causing a rise in the real value of static per capita expenditure on poor relief. ${ }^{32}$

The first date for which local information is available is well after the crisis period of the war years, but the evidence could reflect practice over several decades. In 1821, when wages outside harvest time were about 9-10 shillings a week, the magistrates sitting in Cambridge reckoned that 12 quartern loaves a week, costing 9/6d, should be allowed for families containing four infants, with corresponding figures for other circumstances. This scale was intended primarily as a means of regulating relief to men out of work, but the possibility that it was also used as a scale for subsidising incomes of employed men arises out of a statement made in 1829, again by the magistrates, that income subsidisation (referred to as the making up of wages) should cease. At Melbourn itself the overseers fell into line with this policy, judging by statements made to the JPs in 1829 and to the Par-

31 E. J. Hobsbawm and G. Rudé, Captain Swing (London, 1969), p. 76; Answers to rural queries, op. cit., pp. $60 \mathrm{~b}, 49 \mathrm{c}, 60 \mathrm{c}$; Return showing population, annual value of property, expenditure, rate in the pound, total number of paupers relieved [PP, 1847-48, LIII], pp. 17, 181-83.

32 For a discussion of the distinction between income and wage subsidisation, see McCloskey, "New perspectives on the Old Poor Law", loc. cit. The distinction, however, becomes an academic one when one is confronted with statements such as that by Alfred Power to the effect that in Cambridgeshire the making of allowances for families of those in employment was prevalent, but was not a direct aid to wages, Report on the administration of the Poor Laws, Appendix A, Pt I [PP, 1834, XXVIII], p. 241a. For corn prices see B. R. Mitchell and P. Deane, Abstract of British Historical Statistics (London, 1971), p. 470. I owe this reference and other comments on poor relief to Mr Peter Grey. 
liamentary Commission in 1834, and this may help to account for the fall in per capita expenditure on the poor between 1821 and $1831 .^{33}$

However, the balance between income subsidies and allowances paid to men out of work, often in return for stone digging or some other parish work, is seen to be much less crucial when the scale of the total expenditure on the poor is measured against the normal incomes of the labourers. In 1830 boys were getting $2 / 6 \mathrm{~d}$ to $3 / 6 \mathrm{~d}$ a week, single men (mostly youths) $6 /-$ to $8 /-$, and married labourers $9 /-$ to $12 /-$, rising occasionally to $15 /$ - In 1834 harvest and piece work at other times of the year could yield $12 /-$ to $14 /$ - a week. The average labourer was said to earn $£ 28-30$ per year, exclusive of small beer all the year and ale in harvest time, of which $£$ 3-5 would go on rent. The women and children could do occasional work in harvest and glean for corn, the whole being estimated at a value of $£ 5$ per annum per family. Set against an income, in cash and kind, of about $£ 40$ per year, the per capita levels of expenditure are seen as not amounting exactly to princely sums - perhaps of the order of $£ 5$ per family for all purposes, if spent only among the agricultural labourers (cf. Table 4 with Table 2 for 1831). Another way of expressing the same idea is to note that when Joseph Campkin, the assistant overseer, paid "the labourers" $£ 81$ $10 / 21 / 2 \mathrm{~d}$ in the winter of $1826-27$, probably in a period of frost, this would amount only to ten shillings each, assuming about 160 adult labourers and no payment for boys. ${ }^{34}$

The standard of living of early-Victorian Melbourn cannot be compared with that of previous centuries with any precision, partly because of a shift in emphasis between different income origins for the poorer part of the population. Whereas in 1841 there was a considerable emphasis on wages and poor relief, and apparently very little on subsistence and payments in kind, the emphasis at, say, the end of the seventeenth century can be supposed to have been the other way round. A ratio of no more than 34 farms to 186 labourers in 1841 (Table 3) is a guide to the extent of the proletarianisation of agriculture. In Cambridgeshire generally the rural proletariat emerged as early as the first half of the sixteenth century, but how many of the labourers were entirely without access to arable or to

${ }^{33}$ E. M. Hampson, The treatment of poverty in Cambridgeshire 1597-1834 (Cambridge, 1934), pp. 194-95; House of Lords Committee on Labouring Poor, pp. 386, 398-99; Answers to rural queries, p. 60b. A quartern loaf was more than twice the size of a modern loaf and weighed four pounds or over, cf. J. Burnett, Plenty and want: A social history of diet in England from 1815 to the present day (Harmondsworth, 1968), p. 52.

${ }^{34}$ House of Lords Committee on Labouring Poor, p. 398; Answers to rural queries, pp. 60a, 60b; Town Book I, 1826-27, Cambridgeshire Record Office, P 117/8/1; cf. Rose's view that allowances were not generous, "The allowance system under the New Poor Law", loc. cit., especially pp. 619-20. 
common rights it is not possible to say. However, at the end of the seventeenth century Melbourn contained 125 households (at the hearth-tax collection of 1674), of whom 31 were excused payment of tax. As there were 131 common rights in 1839 and the Town Book suggests no alteration in their number during the eighteenth century, a ratio of one common right per household in 1674 is possible. If we assume that the 31 poor households had no common rights it would mean that $90-100$ households shared these rights, some of the better-off having more than one. This number corresponds very closely with the number of households, practically all nonlabouring, which enjoyed grazing rights for cows in 1839. The point of these calculations is to show that the growth of population in the late eighteenth and early nineteenth centuries made it quite impossible, given the arrangement of the common arable fields and wastes, for all 326 households of 1841 to enjoy the milk and meat supply that had probably been taken for granted in the seventeenth century. In the debate about the standard of living in the early nineteenth century, comparisons of this kind with the situation two centuries before have been neglected, although they may have been implicit in the contemporary arguments based on folk memory. ${ }^{35}$

This line of thinking is reinforced by the generally acknowledged growth in the size of farms, another trend putting direct subsistence out of reach of increasing proportions of the population. The importance of grazing for cows is also demonstrated by the anxious promulgation of regulations in 1725,1732 and 1758, and the expulsion in 1835 of cows belonging to persons who did not have common rights for this purpose. In several neighbouring villages enclosure was followed by a severe reduction in the number of cows being kept, the implication being that some common rights were not adequately compensated by land, or that non-commonright holders had been grazing cows, or both. At Waterbeach, in the fens a few miles north of Cambridge, for example, the number of milk cows had gone down from 600 to 100 since enclosure, so the poor man had to exist on bread and potatoes. Ironically at Foxton, in the late eighteenth century, a lack of cottagers willing to put cows on the town pasture has been recorded, but this could be interpreted as an inability to meet the capital outlay, as much as an unwillingness to procure their own subsistence. ${ }^{36}$

35 Melbourn tithe survey, Cambridge University Library; Enclosure award, Cambridgeshire Record Office; 1841 Census enumeration; Hearth tax, Public Record Office, E 179/244/23; Spufford, Contrasting communities, op. cit., p. 33; Town Book I. Sheep masters were an even smaller elite of sizeable farmers.

36 Town Book II, p. 8; Gooch, General view, pp. 58-60, 75, 80; R. Parker, The common stream (London, 1975), pp. 208-09, 241; J. Denson, A Peasant's voice to landowners (London, 1830), p. 19. 
While by 1839 common rights for most labourers had come down to nothing much besides the possibility of gathering gorse, there is some chance that they may have been allowed to dig plots of land for food crops. A very large number of the labourers, however, lived in tenements with virtually no gardens, and in 1829 Melbourn was reported to be the only parish in the Royston division where the labourers had neither gardens by the house nor separate allotments. By 1834 this situation had been ameliorated, as the overseer reported that some of the best land in the vicinity was let to labourers in pieces of one quarter to half an acre, at $£ 110 /-$ per acre, free of tithe and rates. Unless this land was common field that had been fenced off, there is unlikely to have been large amounts of it, as the small closes near the village would be at a premium for hay, poultry, and grazing during the winter. After the enclosure of 1839 there may have been a substantial increase, for the vicar stated in 1848 that he let his enclosed glebe land to labourers "without a question as to their religion". Yet the only surviving list of allotment holders (from 1858), probably on a different piece of ground, contains only seven names, and most of these were farmers and tradesmen. The difference that half an acre of land could make to a labourer's household economy at this time is well demonstrated by John Denson of Waterbeach, who showed that it was possible, given favourable soil conditions, to live entirely off three acres of garden ground. ${ }^{37}$

The Melbourn overseer of 1834, William Crole Carver, claimed that labourers' families subsisted on their earnings and were robust, but perhaps William Burr, the churchwarden of Meldreth, the next village, was nearer the mark when he admitted that the labourers did not do very well, living on bread and potatoes. The wholemeal flour of their period, when it was not adulterated, contained much higher levels of protein than modern flour and gleaning would have enabled families to acquire some of their own cereals directly. The importance of potatoes should also be emphasised, as they were a new crop in this period, they contain vitamin C (in common with fresh fruit) and their yield of nutritional value per acre is greater than that of cereal crops. Both barley and potatoes could also be fed to pigs, of which there were 600 in Melbourn when crop returns started in 1867 , but if labourers kept them it would be interesting to know

${ }^{37}$ House of Lords Committee on Labouring Poor, pp. 398-99; Answers to rural queries, p. 60b; Cambridgeshire Record Office, P 117/4/1, p. 12; Town Book III, p. 78; Denson, A Peasant's voice, op. cit., pp. iv-vi. For a comprehensive discussion of allotments, see the chapter by D. C. Barnett in Land, labour and population. 
whereabouts, having regard to the cramped conditions of many tenement rows. ${ }^{38}$

Even accommodation for humans must have presented something of a problem in a period of poverty and rapidly rising population. The Morning Chronicle at the mid century gives harrowing accounts of housing conditions in the rural areas around Melbourn, including absolute lack of space, dampness, lack of sanitation, polluted water supplies, in fact, all those conditions known so well in the contemporary urban scene. The public conscience in Melbourn appears to have first stirred in 1847, when the question of drainage of private yards into the public roads was debated by the vestry meeting. The minor landlords of open villages, of whom there were many in Melbourn (Table 5), were notorious for the low standards of their cottage property, built for profit in an age before public housing ventures, when only the landlords of great estates could afford to regard the building of cottages as a public service. ${ }^{39}$

In structural terms there were two main options open to a village like Melbourn; either the larger farm houses could be split up into separate dwellings or new small tenement cottages without significant outbuildings or garden could be built. Both solutions were adopted by 1839 , when the tithe survey gives a good indication as to the types of property, especially when used in conjunction with the enumeration of 1841 . The option of using farmhouses was more limited in Melbourn than in many parishes which had been enclosed at an earlier date, where the building of new farmsteads in the fields caused farmhouses in villages to become redundant. Nevertheless, of the 54 better houses in Melbourn in 1841, at least nine had been divided up between 22 households. Not less than 204 of the 326 households lived in tenements or tenements combined with homesteads. Tenements were the smallest size of cottage and all except 29 of the 204 households lived in accommodation where there was more than one family under the same roof. Tenement rows of from three to thirteen units

38 Answers to rural queries, p. 60b; Parker, The common stream, op. cit., p. 212; Thompson, The making of the English working class, op. cit., p. 347. E. Porter, Cambridgeshire customs and folklore (London, 1969), p. 370, records the eating of blackbird pie, nor should we overlook the possibilities of poaching.

39 Letters XXXVI and XXXVII in the Morning Chronicle, May 8 and September 27, 1850, and letters reprinted in The Victorian working class, ed. by P. E. Razzell and R. W. Wainwright (London, 1973); Town Book II, p. 173; Gooch, General view, pp. 30-31. 
Table 5. Melbourn, owners of cottage property 1839-41

Description of owners

Number

Living in own
tenement

Total
tenements
owned

Agricultural labourers

Building trades

Farmers

Landlord class (includes Melbourn parish and St Peter's College, Cambridge)

Others resident in Melbourn, mainly tradesmen, craftsmen and publicans

Others non-resident

\begin{tabular}{rrr}
10 & 10 & 24 \\
10 & 7 & 46 \\
11 & - & 54 \\
& & \\
5 & - & 32 \\
& & \\
17 & 9 & 54 \\
6 & - & 15 \\
\hline 59 & 26 & 225
\end{tabular}

For technical reasons the totals given here do not tally exactly with the text, where a stricter form of house repopulation is quoted.

Source: Tithe survey 1839; Census enumeration 1841.

gave shelter to at least 143 households or about 40 per cent of the population. ${ }^{40}$

In South Cambridgeshire, clunch and clay bat, under roofs of thatch, were the traditional building materials used by the small owners, who were generally tradesmen or small farmers and only occasionally labourers. Unlike the large-estate owners they could not afford to branch out into the use of new, more durable materials, such as well-baked brick or Welsh slate. Clunch is the name given to the harder chalk quarried from seams of Melbourn rock in pits to the south-east of the village. Even these harder forms of chalk cannot be left open to the full force of the weather, with the result that such walls are plastered and look to the casual observer indistinguishable from lath and plaster in a timber frame (of an earlier period) or from clay-bat walls of a similar age.

Regarding the latter, the Melbourn tradition is that poorer folk would go down to the moor and dig out lumps of clay (chalk marl), which they mixed with chopped-up straw, rags, cow and horse dung, and anything else that came to hand. The resulting mixture was made up with "bats" into regular blocks not unlike modern breeze blocks and stacked up to dry in the wind

40 Census enumeration 1841 and Tithe survey 1839. See also D. R. Mills, "The technique of house repopulation: Experience from a Cambridgeshire village, 1841", in: Local Historian, XIII (1978), pp. 86-97; English rural communities, chs 2, 3 and 10; J. Woodforde, The truth about cottages (London, 1969). 
and the sun. So the peasant could gain his materials almost free of charge and he avoided the use of fuel, expensive in a land devoid of coal and short of wood. One imagines that he used a farmer's cart to take the clay bats to the site, receiving this privilege as a payment in kind, if he did not have his own vehicle.

In the 1830's very few labourers owned their own houses in Melbourn, but the small builders would not be above methods such as these. For a village north of Cambridge (Willingham) there is a record of labourers building houses of clay bats for themselves at a cost of $£ 15-30$, or $£ 33$ for one with two rooms and a chamber (upstairs room). This could be achieved by using about 1,000 clay lumps, the main cash outgoings being for normal bricks to build the lower courses, fireplace and oven, and, presumably, for timber and thatching. ${ }^{41}$

The vital statistics of population in Melbourn can also be used to give some indications of the style and quality of life. An analysis of ages at death given in the burial registers of the parish church for the half century 1795-1845 gives an average (median) age at death of 33 for men and 31.5 years for women. These figures are almost certainly too high, since only 76 of the 690 deaths were of children under the age of one year. Melbourn parents were very slow to baptise their children and this would preclude some children from receiving a proper burial of the kind entered in the register. ${ }^{42}$

This is not the place to enter into the debate as to the relative importance of trends in birth and death rates in explaining the increase in population during the Industrial Revolution, especially as some aspects of registration at Melbourn were defective. However, there is some support for the idea put forward by Tranter, working on data in Bedfordshire, the next county to the west, that although infant mortality remained high, adult mortality was lower than in earlier centuries, with the consequence that less families were broken and completed family sizes could be bigger. Mean age at first marriage at Melbourn (1780-1841) was very low - about 22 for women and 23 for men - and second marriages appear to have been relatively few. Despite the defective baptismal record, the mean size of 71 reconstituted families in the same period was 5.69 children, compared with 6.16 for England and Wales in 1861-69 and 2.11 in 1925-29.43

41 Denson, A Peasant's voice, pp. 28-29.

42 Mills, "The christening custom in Melbourn", loc. cit. It is interesting that the Congregationalists overcame the problem of burying unbaptised children by recording the burial simply as the son or daughter of $\mathrm{AB}$ (father's name).

43 N. L. Tranter, "Demographic change in Bedfordshire"from 1670-1800" (Nottingham Ph.D. thesis, 1966), pp. 358-59; E. A. Wrigley, Population and history (London, 1969), p. 197. 
The mental picture of six children and two parents trying to exist in tworoom cottages with one chamber (the better sort of peasant house at Willingham) makes us aware of some of the reasons for high infant-mortality rates, generally reckoned to be about 150 per 1,000 live births below the age of one year, and about 300 below the age of five. ${ }^{44}$ The high infant-mortality rates and the preponderance of single-family households, despite the shortage of housing, conspired to keep mean household size at the relatively modest level of 4.84 persons in 1841 and close to the figure of 4.798 calculated for 100 English communities between 1574 and 1821 . These figures included lodgers, servants and co-resident kin. The estimate of the mean size of conjugal (or nuclear) families at the same date is probably a few points on the high side at 4.71 persons, including the (surviving) parents, because of the failure of the 1841 census always to distinguish between children of the head of household and other children of the same surname. After making allowance for this inflation, the Melbourn figure still seems high compared with the English standard of 3.66 persons and may reflect the exceptional conditions of a youthful age structure as much as the large size of completed families. The difference between the labouring families (4.43) and the non-labouring families (5.17) underlines the premium on space in the tenement cottages, for completed family sizes at 6.1 and 5.9 respectively were very close. There would be every incentive to send out teen-age children to work as servants in other people's households or, in the case of boys, to lodge at farms. ${ }^{45}$

There are certain respects in which the length and quality of life were undeniably improved as compared with the seventeenth century. Plague had died out in 1728 , when "the brown rat had chased out the black rat from the habitations of men in Western Europe, and the free-roaming flee that had afflicted mankind with plague bacillus was exchanged for a nest-loving flea which apparently disliked the flavour of human blood". ${ }^{46}$ Among other improvements in the control of disease were the disappearance of crises of subsistence because of more efficient agriculture and transport and the introduction of inoculation against smallpox in the last

44 R. E. Jones, "Infant mortality in rural North Shropshire 1561-1810", in: Population Studies, XXX (1976), pp. 305-17, especially pp. 305, 308, 315. Thompson, The making of the English working class, p. 361, quotes figures of 250 per 1,000 under age one and 500 per 1,000 for the age group $0-5$ in Sheffield about 1840 .

45 Census enumeration 1841; Household and family in past time, ed. by P. Laslett and $R$. Wall (1972), pp. 83, 87, 133, 214, 235. I have used their Ratio 2 in these calculations, i.e. number of households, excluding institutions (W. C. Carver's school) divided into total population, to arrive at mean household size.

46 J. D. Chambers, Population, economy, and society in pre-industrial England (1972), pp. 150-51. 
quarter of the eighteenth century. ${ }^{47}$ The cottages of the early nineteenth century were probably no worse than those of previous generations, except for the problems created by higher densities - a direct result of population growth unmatched by sufficient changes in the local economy. The lower mean age at death of women in Melbourn as compared with men, an unusual statistic, suggests that deaths from consumption (tuberculosis), a worse disease for those who stayed indoors, and deaths due to childbirth, were important causes of early demise. The gradual loss of direct subsistence over a long period, coupled with inflated corn prices and the reluctance of farmers to pay living wages when faced with a surplus of labourers, combined to make it unlikely that Hodge (the farm labourer) received a fair share of the increased food supply his labours produced. However, actual starvation was staved off by the overseers' willingness to dip into the ratepayers' pockets and for the whimpering child a ha'porth (half-pennyworth) of Godfrey's cordial (laudanum, opium) could be acquired from the newly installed chemist.

47 See the chapter by P. E. Razzell in Population in industrialisation, ed. by M. Drake (London, 1969), for an account of inoculation against smallpox. 